\title{
幼若猫の扁桃体キンドリングについて
}

\section{A Study of Amygdaloid Kindling in Kittens}

川原隆造* 松田和義竹下久 由

田中隆彦石田暁宏大久保敵彦

\begin{abstract}
要旨:未熟脳のけいれん現象を検討するために，幼若猫の扁桃体キンドリングを成猫のそ れと比較した。 5 匹の 3 カ月齢猫（幼猫群）と6 匹の成猫 (成猫群)をキンドリングし, 次の結果を得た。

1) Kindling rate は両群の間に差異はなかったが，幼猫群は stage 4 に速やかに進み, stage 4-5 に長く留まった。幼猫群は成猫群に比し有意に少ない刺激回数と短い $\mathrm{AD}$ 持続 時間で stage 4 に達し，その後最終段階までに有意に多い刺激回数と長い $\mathrm{AD}$ 持続時間 を要した。2）幼猫群の全般性けいれん誘発閾值は成猫群のそれより有意に高かった。

以上の結果から, 幼若猫の辺縁系では抑制系より興奮系が強力で, 全般化機序では興奮 系より抑制系が強力であるらと考觉る。
\end{abstract}

てんかん研究 1988; 6: 111-118

Key Words: amygdaloid kindling, immature brain, kittens, adult cats, AD duration.

\section{はじめに}

けいれん性疾患はいずれの年齢でも見られる が，脳が十分に成熟していない未発達段階に最も 好発する。そして，けいれんの発作型は脳の成熟 に伴い変化することは良く知られている。新生児 の場合，全般性発作は少く，ほとんど部分発作で 2 次全般化発作も起こりにくい12)。乙かし脳の成 熟とともに全般化機序が発達し, 全般性けいれん が出現するようになる。

いっぽう，キンドリング実験モデルは，まず刺 激部位に進行性の後放電の延長が括こり，それが 周囲組織に拡散し, 最終的には大脳運動領の興奮 となり全般性けいれんを呈するものである。した
がって，未熟脳のけいれんの特徵を把握するのに 格好の実験てんかんモデルであるように思われ る。そこで, 今回は 3 力月齢の幼若猫に扁桃体キ ンドリング (AM-K)を行い成猫の AM-K と比較 し, 未熟脳の AM-K の特徵を検討することにし た。

\section{I. 方 法}

本実験の対象は 3 カ月齢の仔猫 5 匹（幼猫群） と成猫 6 匹 (成猫群) である。幼猫群の体重は $1.0 \sim 1.3 \mathrm{~kg}$ で, ネンブタール麻酔下で成茂脳固 定装置を用い Ajmone-Marsan のネコ脳図譜を参 照して右扁桃体 (F：11.0, L：-11.0, H: -5.0) に深部電極を, 左側頭頭頂部硬膜上に皮質電 極

* 鳥取大学医学部神経精神科

[于683 米子市西町 $36-1$ ]

Ryuzo Kawahara, Kazuyoshi Matsuda, Hisayoshi Takeshita, Takahiko Tanaka, Akihiro Ishida, Izuhiko

Okubo

Department of Neuro-psychiatry, Tottori University School of Medicine

1988年 1 月 28 日受理 
を，前頭洞に不関電極をとれぞれ植え込んだ。以 上の電極は日本電子工業製ミニチュアソケットに 導出し, 頭蓋の発達を考慮して, 弾力性のあるシ リコンゴム（信越シリコーン KE457）で頭蓋上に 固定した。右扁桃体の深部電極はステンレススチ ール線（直径 $0.36 \mathrm{~mm}$ ）をより合せた双極電極を 用いた。

手術後 7 日目に後発射閾值 (after discharge threshold, ADT) 測定のため $200 \mu \mathrm{A}$ で 1 秒間, $60 \mathrm{~Hz}$ 正弦波で右扁桃体を刺激した。後発射 (after discharge, AD) が出現しなかった場合には $50 \mu \mathrm{A}$ ずつ刺激強度を上げた。200 $\mu \mathrm{A}$ で後発射 が出現した場合は $50 \mu \mathrm{A}$ ずつ刺激強度を下げ $\mathrm{AD}$ を出現させるのに必要最小限の刺激強度をもって $\mathrm{ADT}$ とした。 $\mathrm{ADT}$ 決定後に 1 日 2 回, 午前 9 時 と午後 6 時に右扁桃体を $\mathrm{ADT}$ で反復刺激した。 全般性けいれんが 5 回出現したところで AM-K 完成とした。その後全般性けいれん誘発閾值 (generalized seizure-triggering threshold, GST)を

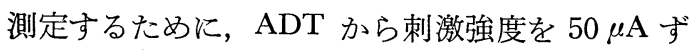
つさげ，全般性けいれんを誘発するに必要最小限 の刺激強度を求め GST とした。

ADT 測定開始から GST 測定終了まで刺激前 後における行動と脳波を観察した。全般性けいれ んに拈いては刺激開始から全般性けいれんが出現 するまでの時間，いわゆる全般性けいれん潜時 (latency of generalized seizure, LGS) を測定し た。GST 測定後, 頭蓋上のミニチュアソケット および電極をすべて抜去し, 成熟後の各種測定に 備えた。そのらち 3 匹はその後死亡したので, 電 極の位置など組織学的に検討した。

成猫は体重 $3.2 \sim 4.0 \mathrm{~kg} 6$ 匹で, 深部電極は右 扁桃体 (F: $-11.0, \mathrm{~L}:+10.5, \mathrm{H}:-6.0)$, 皮 質電極は側頭頭頂硬膜上に，基準電極は前頭洞に それぞれ植え込んだ。電極はステンレススチール 線(直径 $0.36 \mathrm{~mm}$ ) 3 本をより合わせて作成した。 電極はすべて日本電子工業製ミニチュアソケット に導出し、デンタルセメントで頭蓋上に 固定し た。手術 2 週間後に ADT 測定, AM-K の施行, GST 測定は幼猫群と同一とした。

AM-K の発作段階は Wada and Sato ${ }^{15)} の$ 分類 に準じた。すなわち，刺激側顔面搐搦（第 1 段
階， stage 1)，両側顔面搐搦 - 流涎（第 2 段階, stage 2), 点頭 - 散瞳（第 3 段階， stage 3), 刺激 反対側前肢の伸展（第 4 段階, stage 4), clonic jumping (第 5 段階, stage 5), 転倒を伴う全身け いれん（第6 段階， stage 6) に分類した。

\section{II. 結 果}

\section{1. 幼猫群と成猫群の AM-K の比較}

Fig. 1 は 5 匹の幼猫群の AM-K の形成過程を 示したシェーマである。各発作段階の行動は成猫 群のそれとほとんど同じであったが，幼猫群は比 較的早期に stage 4 に達し, AM-K の形成過程 のう兊で成猫群のそれと大きな差異が認められ た。すなわち，初回刺激で stage 4 を示した幼若 猫は 2 匹，他の 3 匹は $3,6,7$ 回の刺激で stage 4 に達した。その後 stage 4,5 が比較的安定して 続き， stage 6 に達した猫が 3 匹で，不安定で退 行現象の認められた猫は 2 匹であった。しかし， 全般性けいれんが出現するに要する全刺激回数は 幼猫群と成猫群との間に大きな差異はなかった。

そこで，代表的 1 例 (Fig. 1 の最上段) につい て脳波と行動について示すと(Fig. 2), この猫は初 回刺激で両側顔面搐搦 (bilateral facial twiching, BFT), 点頭 (head nodding, HN), 対側前肢の強 直伸展 (tonic extensor, TE) を呈し, $\mathrm{AD}$ 持続時 間は39秒で stage 4 であったが，その後の刺激で $\mathrm{AD}$ は少しずつ延びているものの stage 4 が安定 した形で持続し，全般性けいれんに達するまでに 14回の刺激を要した。7回目と12回目の刺激に対 する反応は stage 4 であった。15回目の刺激で全 般性けいれんを呈したが，その時の行動変化は対 側への回旋運動 (circuling, Cir), HN, BFT, 対 側前肢の TE, 跳躍運動 (clonic jumping, Jamp), 前肢間代けいれん（forelimb clonus，FLC) を経 て全般性けいれんに至った。

次に AM-K を stage 1-3 の部分けいれんの段 階と stage 4-5 の全般化の段階に分けた。そし て, 全般性けいれんが誘発されるまでの stage 1-5 の全経過, stage 1-3, stage 4-5 について, 刺激 回数と $\mathrm{AD}$ 持続時間累計を算出したのが Table 1 である。

まず全般性けいれんが出現するまでの全経過に 

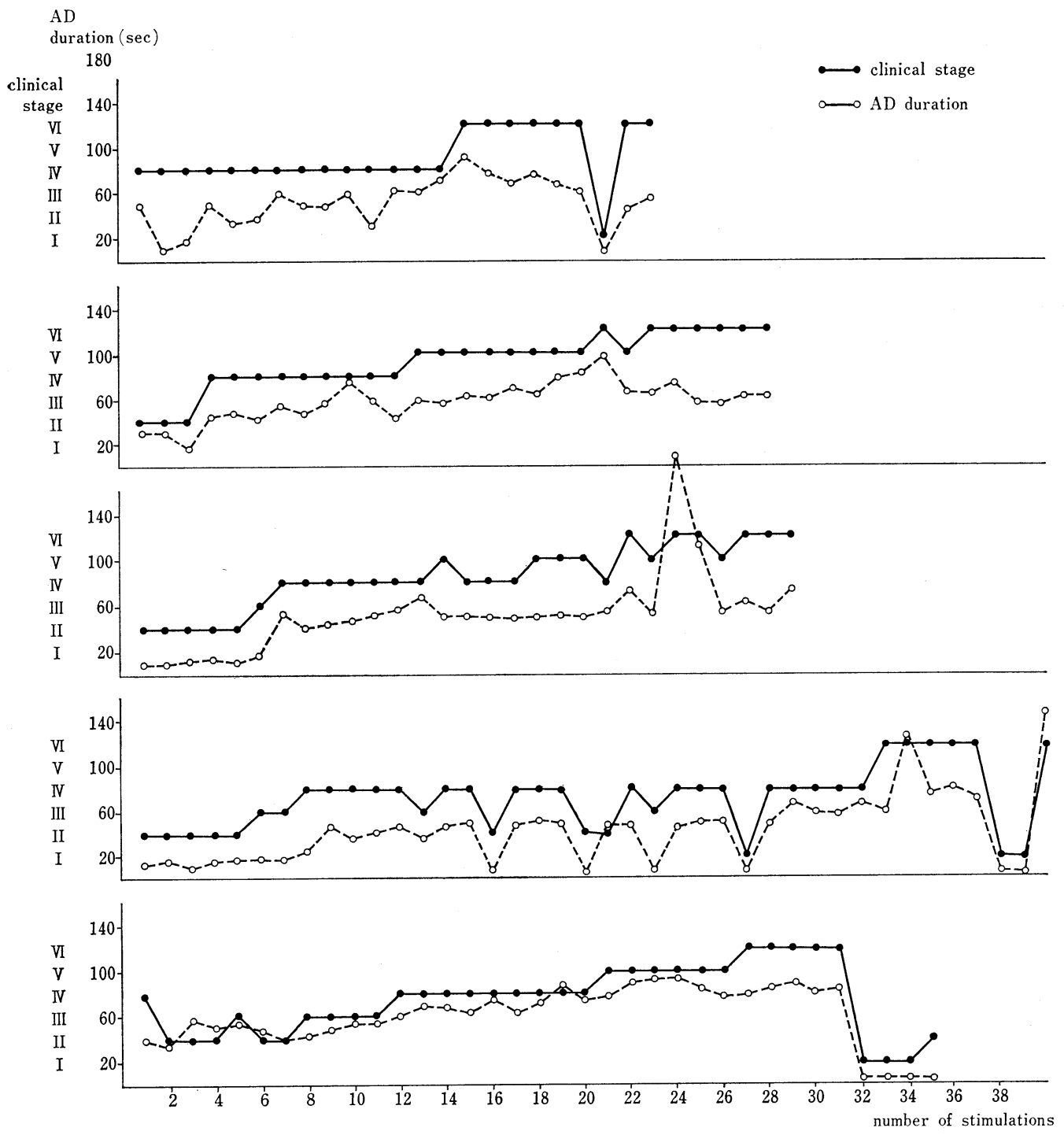

Fig. 1 Development of amygdaloid kindling in kittens

ついてみると, 幼猫群の kindling rate の平均值 と標準偏差は $22.6 \pm 6.1$ 回, 成猫群のそれは 21.7 士5.9回で両群の間に差異はなかった。しかし，部 分けいれん，すなわち stage 1-3 に要した刺激回 数は幼猫群で $3.2 \pm 2.7$ 回であったのに対して, 成 猫群のそれは $15.5 \pm 3.7$ 回で, 前者が有意に低值 であった。いっぽう全般化の時期である stage 45 に要した刺激回数は幼猫群で 19.4 55.1 回, 成 猫群で $6.2 \pm 5.1$ 回で, 前者が有意に 高值であっ た。すなわち, 幼猫群は stage 4 までは速やかに
形成されるが，その後全般性けいれんが出現する までにはより多くの刺激を必要とすることがわか った。そこで, stage 1-3 までの刺激回数と stage 4-5 の刺激回数を AM-K 完成までの刺激回数の 百分率として算出すると, Fig. 3 亿示すよらに, 幼猫群の stage 1-3 の刺激回数の全刺激回数に対 する百分率の平均值と標準偏差は $13.1 \pm 11.5 \%$,

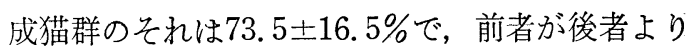
有意に低值であった $(\mathrm{p}=0.002)$ 。いっぽう幼猫 群の stage 4-5 の刺激回数の全刺激回数に対する 

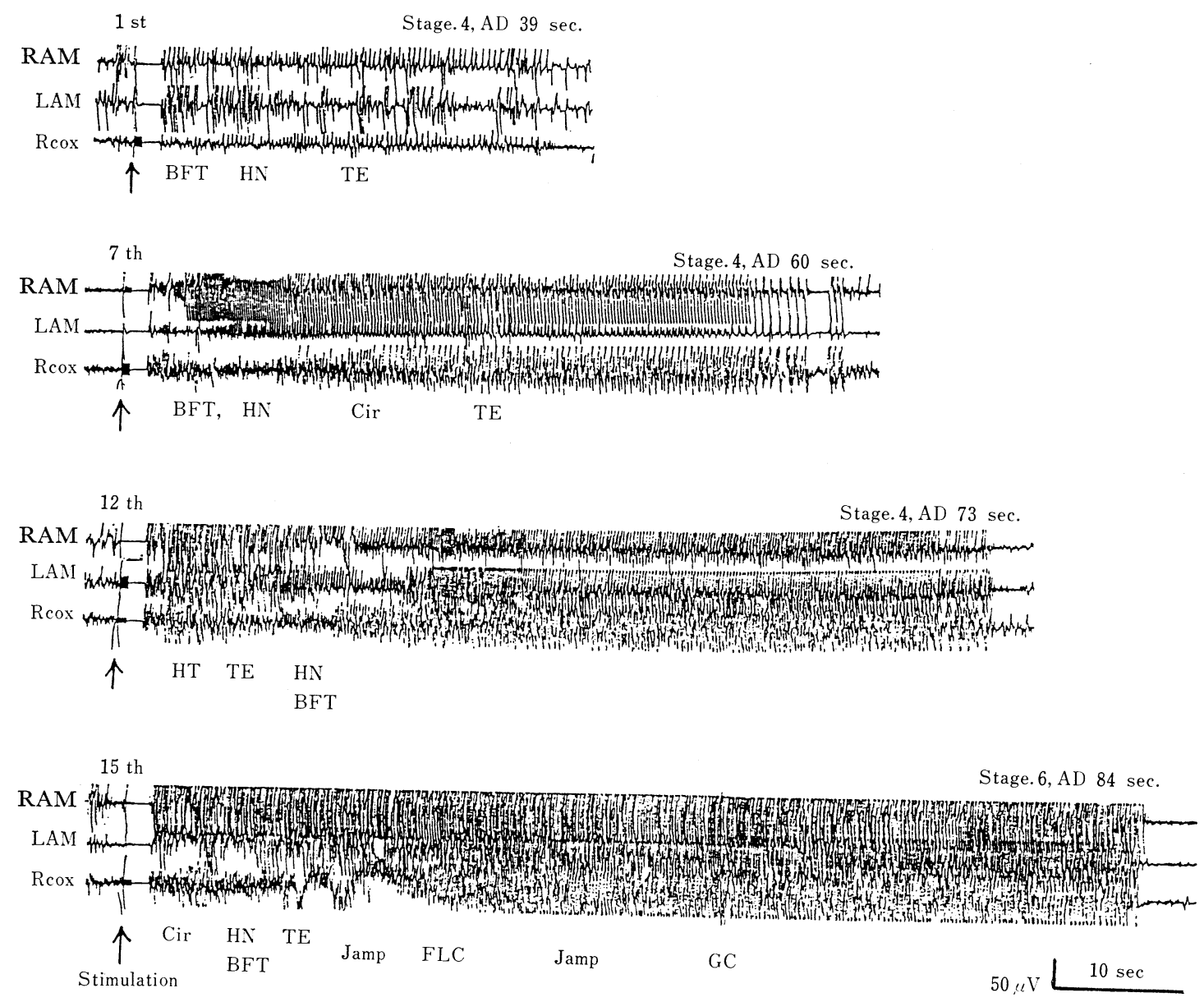

Fig. 2 The amygdaloid kindling of a kitten cat

Table 1 Stimulation numbers, AD duration in kitten and adult group

\begin{tabular}{l|lc|c|c}
\hline & & Kitten group & Adult group & \\
\hline & stage 1-3 & $3.2 \pm 2.7$ & $15.5 \pm 3.7$ & $\mathrm{p}=0.002$ \\
stimulation & stage 4-5 & $19.4 \pm 5.1$ & $6.2 \pm 5.1$ & $\mathrm{p}<0.004$ \\
numbers & kindling rates & $22.6 \pm 6.1$ & $21.7 \pm 5.9$ & $\mathrm{NS}$ \\
\hline & stage 1-3 & $46.4 \pm 38.9$ & $392.0 \pm 155.3$ & $\mathrm{p}<0.002$ \\
$\begin{array}{l}\text { AD duration } \\
\text { (sec.) }\end{array}$ & stage 4-5 & $1008.8 \pm 363.8$ & $278.0 \pm 259.7$ & $\mathrm{p}<0.009$ \\
& stage 1-5 & $1055.2 \pm 356.8$ & $670.0 \pm 186.8$ & $\mathrm{p}<0.026$ \\
\hline
\end{tabular}

百分率の平均値と標準偏差は $86.7 \pm 11.5 \%$, 成群 のそれは26.5土16.5\%で，前者が後者より有意に 高值であった $(\mathrm{p}<0.004)$ 。

$\mathrm{AD}$ 持続時間については，幼猫群の stage 1-3 の $\mathrm{AD}$ 累計の平均値と標準偏差 $46.4 \pm 38.9$ 秒に
対して成猫群のそれは392.0 後者より有意に短かかった $(\mathrm{p}=0.002)$ 。 stage 4-5 の AD 累計については, 幼猫群の 1008.8土 363.8 秒に対して成猫群のそれは278.0土259.7秒 で，前者が後者より有意に延長していた（ $\mathrm{p}=$ 


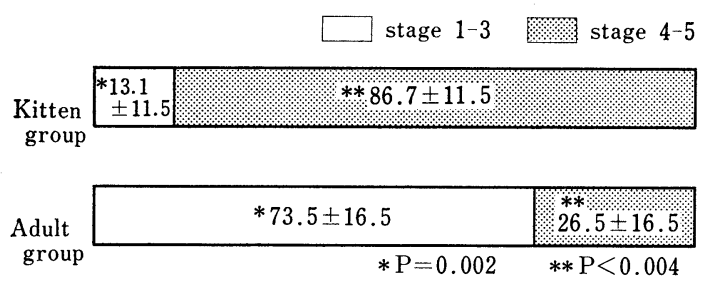

Fig. 3 Percentage of stimulations number of each stage $1-3$ and stage $4-5$

stage 1-3 \%ala stage 4-5

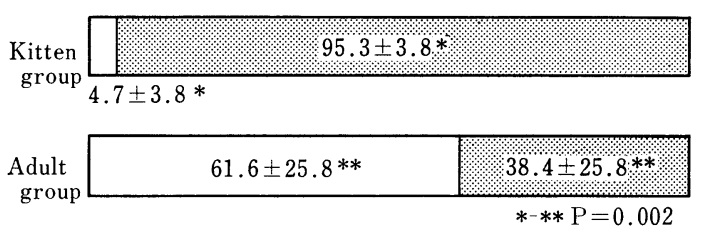

Fig. 4 Percentage of cumulative $\mathrm{AD}$ duration of each stage $1-3$ and stage $4-5$

0.009)。なお, stage 6 が形成されるまでに要し た $\mathrm{AD}$ 持続時間の合計を比較すると，幼猫群が 1055.2 2356.8 秒, 成猫群が $670.0 \pm 186.8$ 秒で, 前者が後者より有意に延長していた $(\mathrm{p}=0.026) 。$ そこで, 刺激回数と同様に, stage 1-3 と stage 45 のそれぞれについて $\mathrm{AD}$ 持続時間全体に対する 百分率で見ると (Fig. 4), 幼猫群の stage 1-3の 百分率の平均值と標準偏差はわずか $4.7 \pm 3.8 \%$ で

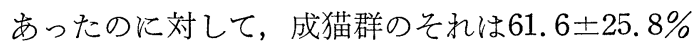
で，前者が後者より有意に低值であった（ $\mathrm{p}=$ 0.002)。 stage 4-5 の占める割合については，幼 猫群の $95.3 \pm 3.8 \%$ が成猫群の $38.4 \pm 25.8 \%$ より 有意に高值であった $(\mathrm{p}=0.02)$ 。

\section{ADT, GST について}

一般に成猫では，ADT でキンドリングすると 次第に ADT が低下し，キンドリング完成時の GST は ADT より有意に低下する。そこで両群 のADTとGSTを比較してみると, 幼猫群の ADT

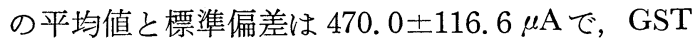
のそれは $350.0 \pm 190.5 \mu \mathrm{A}$ であった。前者が後者 より高值であったが有意差はなかった。それに対 して, 成猫群の ADT の平均値と標準偏差は 283.3 $\pm 157.1 \mu \mathrm{A}$ であったのに対して GST のそれは 133. $3 \pm 49.2 \mu \mathrm{A}$ で前者が後者より有意に高值で

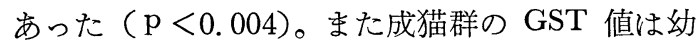

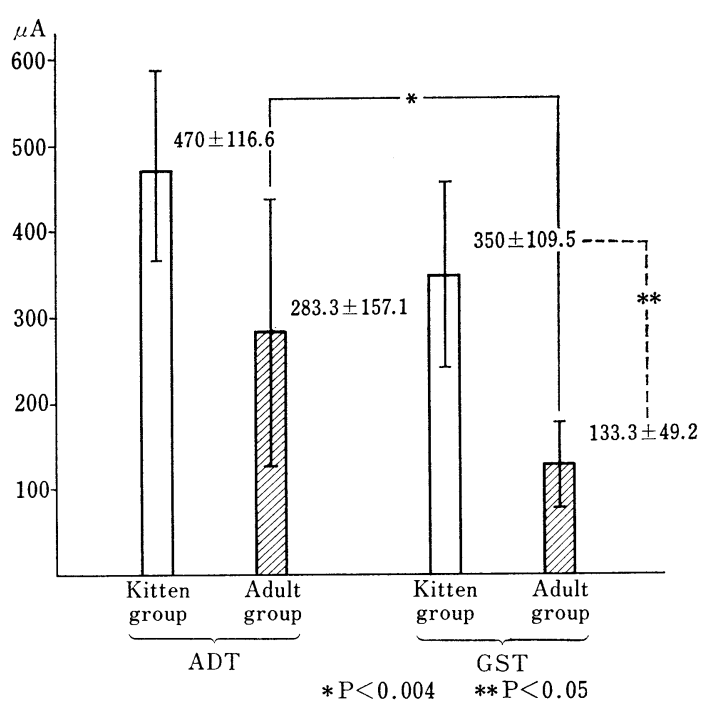

Fig. $5 \mathrm{ADT}$, GST of kitten and adult group

猫群のそれより有意に低值であった（ $\mathrm{p}<0.05) 。$ な拉 GST 值を ADT 值で除した值はその值が低 いほど全般性けいれんの興奮性の高いことを示す ものであるが，幼猫群の GST/ADT 值の平均值

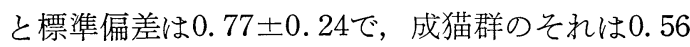
土0.26で，後者が前者より低值であったが有意差 はなかった。次に初回と第 5 回目の全般性けいれ んの $\mathrm{AD}$ 持続時間と LGS について比較すると, 幼猫群の初回全般性けいれんの $\mathrm{AD}$ 持続時間の平 均值と標準偏差は80.4 12.2 秒, 成猫群のそれは 87.0土17.6で，両者の間に差異はなかった。 5 回 目の全般性けいれんの $\mathrm{AD}$ 持続時間について見る と, 幼猫群の $\mathrm{AD}$ 持続時間の平均值と標準偏差は 66. $2 \pm 11.8$ 秒, 成猫群のそれは48.7士21. 1秒で, 前者が高值であったが有意差はなかった。LGSに ついてみると, 初回全般性けいれんの幼猫群の平 均值と標準偏差は 46.0土14.0秒, 成猫群のそれは $42.7 \pm 19.7$ 秒で両者の間に大差はなかった。 5 回 目の全般性けいれんについても幼猫群の LGS は

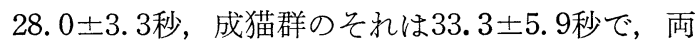
者の間に差異はなかった。

\section{III. 考察}

\section{1. 脳の発達と kindling}

今回得られた幼若猫の AM-K は，きわめて少な い刺激回数で stage 4 に進み, その後全般性けい 
れんが出現するまでに多くの刺激回数を要すると の結果を得た。この結果は未熟脳のいかなる特徵 を示しているのであろらか。その手がかりを得る ために，まずキンドリングの形成過程について触 れてみる。キンドリングはきわめて微弱な電流を 反復して与えることにより, 初めは限局性の変化 であったものが，経シナプス性にてんかん性変化 を与え，辺縁系諸核を巻き込み，さらに中脳網様 体, 視床諸核に epileptic discharge が伝播され, 最終的には全般性けいれんを呈するに至る。AM$\mathrm{K}$ の発作各段階と脳内の epileptic discharge の伝 播を対比してみると, stage 1-2は顔面のれん縮で, この時期は同側の海馬掞よび対側の扁桃核・海馬 への伝播が認められる時期で, 辺縁系の興奮の時 期である。stage 3 は顔面のれん縮と head nodding の症状が見られ，脳内では皮質への伝播や stage 3 の後期には皮質下諸核への伝播も認められる。 stage 4 は対側前肢の伸展, 頭部の対側への屈曲, 反 対方向への回旋運動などを伴い，始めて全身運動 が認められる発作段階である。脳内ではこの段階 に皮質下諸核への広沉な伝播が認められる。 stage 5 は四肢の律動的屈伸運動, stage 6 は転倒と全 身の強直ないし間代けいれんで, 全般化の完成す る時期である ${ }^{15)}$ 。脳内の epileptic discharge の伝 播の面から見ると, stage 3 の後半から全般化が 始まるが，行動面では部分発作であることから stage 1-3 を部分けいれん期, stage 4-5を全般化 期に分けてみることにした。

今回の 結果を stage 1-3 と stage 4-5 に分けて 両群を比較すると, 幼猫群では全般化に費やされ る刺激回数が著しく多く, 成猫群の約 3.1 倍であ った。 $\mathrm{AD}$ 持続時間についても，幼猫群の全般化 に要する $\mathrm{AD}$ 持続時間は成猫群の 約 3.6 倍であ った。幼猫群の stage 4-5 に怙汗る多くの刺激回 数と長い $\mathrm{AD}$ 持続時間といら 2 つの所見は同一方 向のものであるように思う。 $\mathrm{AD}$ 持続時間はてん かん性放電の回数に比例するので, 幼若猫は全般 化の時期である stage 4-5 で多くの刺激回数とて んかん性放電を必要とするものと考えることがで きる。

発達とキンドリングに関しては, すでにラット についていくつかの報告がある。例觉ば Gilbert et al.7) によると, neonate (10日), infant(14日) のラットの AM 刺激に対する最大反応は部分け いれんか不完全なキンドリング発展を呈するが， 21日以上になると成熟ラットと同様のキンドリン グ発展を示したと報告している。生後15～18日目 の suckling rat の85\%に，34〜72日のラットの96 \%に $\mathrm{AD}$ の発展と全般性けいれんが認められた が, suckling rat のキンドリングは成熟ラットの それと異なった行動変化を示したとのことであ る。その suckling groupでは, 発作段階 $\mathrm{C}_{3-4}$ の 全般化けいれんの発展に要する時間が成熟ラット のそれより延長していたのに反して，成熟ラット では発作段階 $\mathrm{C}_{1}$ (顔面けいれん) が suckling rat より延長していたという ${ }^{9)}$ 。この結果は, 今回の われわれの猫での実験結果と類似している。 Moshé, et al.8) は発達とADT について調べた ところ，ADT は年齢とともに変化し， suckling group の ADT は最高で, 60日や84日齢のラット の $\mathrm{ADT}$ より有意に高值であったと報告してい る。なお， Moshé, et al. ${ }^{10)}$ は 15 分と 60 分の 2 種 類の刺激間隔で suckling rat と成熱ラットをキン ドリングしたところ， suckling rat は15分，60分 の両方の刺激間隔で同様にキンドリングが形成さ れた。しかし，成熟ラットは 15 分間隔の刺激で 著しい退行現象を生じた。このことは, suckling rat が short seizure refractory period を有するこ とを示している。

以上の報告をまとめると neonate(10日), infant （14日）では部分けいれんあるいは不完全な 発作 発展を呈する。生後15～18日齢の suckling rat で は成熟ラットとほぼ同じ kindling rate で形成され るものの， $\mathrm{C}_{3-4}$ 段階に多くの刺激回数を要した。 そして suckling ratの ADTは成熟ラットのそ れより有意に高值であった。21日齢以上になると 成熟ラットのキンドリング発展とほとんど同じで あった。今回の 3 カ月齢の幼猫群のキンドリング 所見は suckling rat のキンドリング所見と類似の 点が多い。次に未熟脳の中枢神経系について考察 する。

\section{2. 未熟脳の中枢神経系}

成熟につれて seizure susceptibility が変化する のは中枢神経系の 細胞の未熟性の他，1）先端樹 
状突起の発達，2）軸索の発達，3）各伝達物質の シナプス形成などが深く関与しているものと考兄 る。この方面に関するラットでの報告をみると， ラット大脳皮質先端樹状突起の伸展は18日までに 成熱ラットと同程度に成長する ${ }^{5)}$ 。このことは21 日齢のラットがほぼ正常キンドリングを呈するこ とと深い関係があるように思われる。また 21 日よ り若いラットの不完全なキンドリングは未熟な軸 索と関連していると考えることもできる。軸索形 成に関して，第 1 相は10〜30日で，この時期には 薄いスムースな軸索が形成され，第 2 相は $30 \sim 40$ 日で厚くて完全な軸索が形成される ${ }^{1)}$ 。完全な軸 索の形成がキンドリングの発達と関係していると 思わ机る。したがって21日齢の kindling が全く成 熟ラットのキンドリングと同一のものであるか否 か今後検討する必要がある。

神経伝達物質については, norepinephrine と その合成酵素は胎生期の脳に存在し, 出生から adulthood にかけて直線状に漸次増大する ${ }^{3,11}$ が, acethylcholine の合成酵素である choline acethyltransferase の濃度は出生後きわめてゆっくり上昇 し24日で peak に達する4)。すなわち抑制系の神 経伝達物質とされているカテコールアミン系と GABA 系の成熟は興奮系のコリン系の成熟より 先行している ${ }^{2,14)}$ 。幼若猫の中枢神経系にも同様 飞軸索形成, 先端樹状突起, 神経伝達物質系の未 熟性が存在するものと思われる。

幼若猫の AM-K では, 5 匹中 2 匹が第 1 回目 の刺激で stage 4 を呈し, 他の 3 匹も極めて少な い刺激回数で stage 4 に達した。このことは幼若 猫の辺縁系が電気刺激に対して鋭敏に反応するこ とを示している。しかし, 幼猫群の ADTは成猫 群のそれょり高值で, 一見矛盾する結果であっ た。この点に関するラットでの報告をみると， $\mathrm{ADT}$ の高い系のラットは低い系のラットより少 ない刺激回数でキンドリングが完成した ${ }^{16)}$ 。ラッ トの背側海馬のキンドリングは腹側海馬のキンド リングと比べ，低い ADT で多くの刺激をキンド リング 完成までに 要した ${ }^{13)}$ 。35日齢のラットの $\mathrm{ADT}$ は他の年齢群のそれより有意に低かったが, kindling rate は他の年齢群より有意に延長してい たとの報告がある8
以上の点より ADT 值と kindling rate は必ず しも相関するものではなく, むしろ逆相関の関係 にある。つまり, 今回の幼猫群の高い ADT 值と第 $1 \sim 3$ 段階の少ない刺激回数はラットに打ける実 験結果と同じ方向の所見であるように思われる。

キンドリング形成過程に関与する神経機構は興 奮系の活動六進だけでなく抑制系の活動六進の可 能性がある ${ }^{6)}$ 。この点を考慮して今回の結果をみ ると, 幼若猫の辺縁系の興奮系は抑制系より鋭敏 であるが，全般化機序に関しては興奮系より抑制 系の方が優位ではないかと考える。

\section{おわりに}

幼若猫の AM-K の特徵を把握するために, 3 カ 月齢の幼若猫 5 匹 (幼猫群) と成熟猫 6 匹（成猫 群)について AM-K を行い, キンドリングの形 成過程和よび全般性けいれんについて比較検討 し, 次の結果を得た。

1) 幼猫群は成猫群に比し, 第 4 段階までは速 やかに形成され，有意に少ない刺激回数であった が，その後第 6 段階が完成するまでに成猫群より 有意に多い刺激回数を要した。しかし, 両群の kindling rate に差異はなかった。

2) $\mathrm{AD}$ 持続時間について, 幼猫群の第 4 段階 が形成されるまでに要する第 1 段階の $\mathrm{AD}$ 持 続時間累計は成猫群のそれより有意に短かった。 しかし，その後第 6 段階が形成されるまでの幼猫 群の $\mathrm{AD}$ 持続時間累計は成猫群のそれより有意に 延長していた。

3) GST については, 幼猫群の GST が成猫 群のそれより有意に高かった。また, 前者の $\mathrm{ADT}$ は後者のそれより高值であったが，有意差はなか った。なお, 両群の ADT と GST の差について みると, 成猫群の ADT は GSTより有意に高值 であった。いっぽう幼猫群の ADT は GSTょり 高値であったが，有意差はなかった。

以上の結果から, 幼若猫の辺縁系では抑制系よ り興奮系が強力で, 全般化機序では興奮系より抑 制系が強力であろらと考える。

\section{文 献}

1) Agrawal HC, Davidson AN, Myelination and 
amino acid imbalance in the developing rat brain a quantitative electron microscope study. Brain Res 1967; 6: 716-727.

2) Arnold PS, Racine RJ, Weise RA. Effects of atropine, reserpine, 6-hydroxydopamine, and handling on seizure development in the rat. Exp Neurol 1973; 40: 457-470.

3) Coyle JT, Axelrod J. Dopamine-ß-hydroxylase in the rat brain: developmental characteristics. J Neurochem 1972; 19: 449-459.

4) Coyle JT, Yamamura HI. Neurochemical aspects of the ontogenesis of cholinergic neurons in the rat brain. Brain Res 1976; 118: 429-440.

5) Eayrs JT, Goodhead B. Postnatal development of the cerebral cortex in the rat. J Anat 1959; 93: 385-401.

6) Engel J Jr, Ackermann RF. Interictal EEG spikes correlate with decreased, rather than increksed, epileptogenecity in amygdaloid kindled rats. Brain Res 1980; 190: 543-548.

7) Gilbert ME, Cain D. A developmental study of kindling in the rat. Develop Brain Res 1982; 2: $321-328$.

8) Moshé SL, Sharpless NS, Kaplan J. Kindling in developing rats: variability of afterdischarge thresholds with age. Brain Res 1981; 211: 190195.
9) Moshé SL. The effects of age on the kindling phenomenon. Develop Psychobiol 1981; 14:7581.

10) Moshé SL, Albala BJ, Ackermann RF, et al. Increased seizure susceptibility of the immature brain. Develop Brain Res 1983; 7: 81-85.

11) Porcher W, Heller A. Regional development of catecholamine biosynthesis in rat brain. J Neurochem 1972; 19: 1917-1930.

12) Purpura DP. Stability and seizure susceptibility of immature brain. In: Jasper $\mathrm{HH}$, Ward AA, Pope A (eds) Basic mechanisms of epilepsies. Boston: Little Brown and Company, 1969; 481.

13) Racine R, Rose PA, Burnham WM. Afterdischarge thresholds and kindling rates in dorsal and ventral hippocampus and dentate gyrus. Canad J Neurol Sci 1977; 4: 273-278.

14) Vosu H, Weise RA. Cholinergic seizure kindling in the rat: comparison of caudate, amygdala and hippocampus. Behav Biol 1975; 13: 491-495.

15) Wada JA, Sato M. Generalized convulsive seizure induced by daily electrical stimulation of the amygdala in cats. Neurology 1974; 24: 565-574.

16) Zaide J. Differences between Tryon Bright and Dull rats in seizure activity evoked by amygdala stimulation. Physiol Behow 1974; 12: 527-534.

\title{
Summary
}

\section{A Study of Amygdaloid Kindling in Kittens}

\author{
Ryuzo Kawahara, Kazuyoshi Matsuda, Hisayoshi Takeshita, \\ Takahiko Tanaka, Akihiro Ishida, Izuhiko Okubo
}

With a wish to understand the epileptic phenomenon in the immature brain, we compared the development of amygdaloid kindling in kittens with that in adult cats. Five kittens (kitten group) and six adult cats (adult group) were subjected to kindling preparation, and the results obtained were as follows:

1) Although the kindling rates between kitten and adult groups were similar, kittens reached kindling stage 4 quicker and remained longer at stages $4-5$. To arrive at kindling stage 4 , the kitten group needed significantly fewer stimulations and a shorter AD duration, after which many stimulations and a longer $\mathrm{AD}$ duration were needed to arrive at the final stage in comparison with the adult group.

2) The GST of the kitten group was significantly higher than that of the adult group.

From these results, we were able to conclude that the excitatory system should be stronger than the inhibitory system of the kitten limbic structure, whereas the inhibitory system of the generalized epileptic mechanism should be stronger than the excitatory system in the kitten brain. 